\title{
Lęk przed monizmem: Potworność, parapolityka i nowożytne źródła filozofii porównawczej
}

Poniższy tekst analizuje sposób przedstawienia monizmu jako doktryny usytuowanej na przecięciu europejskich i azjatyckich tradycji filozoficznych. Prezentacja stanowiska monistycznego w kategoriach potworności, charakterystyczna dla głównego nurtu nowożytnej myśli europejskiej, osadzona zostaje w szerszej perspektywie parapolitycznej krytyki pojęcia suwerenności oraz koncepcji kosmicznego horroru. Zestawienie to opiera się na równoczesnej lekturze przypisów do hasła "Spinoza” w Stowniku krytyczno-historycznym Pierra Bayle'a oraz opowiadania Zew Cthulhu Howarda P. Lovecrafta. W konkluzji artykułu przekonuję, że monizm należy traktować jako jeden z nurtów kolektywistycznie zorientowanej ontologii politycznej. Ontologia taka może stanowić podstawę dla nowego modelu studiów porównawczych, zbudowanych wokół pojęcia dóbr wspólnych i krytycznych wobec nowoczesnej aparatury poznawczo-politycznej, podtrzymującej i naturalizującej procesy akumulacji pierwotnej. 
Jedynie od bardzo wiekowego Metysa nazwiskiem Castro policja zdołała nieco wyciągnąć, on zaś utrzymywał, że zawijał do różnych dziwnych portów i tam rozmawiał z nieśmiertelnymi wodzami kultu, żyjącymi pośród gór w Chinach.

Howard P. Lovecraft, Zew Cthulhu, 1926

\section{Uwagi wstępne}

Punktem zaczepienia dla poniższego artykułu są dwa - pozornie niezwiązane ze sobą i niewspółmierne filozoficznie - spotkania, czy raczej perforacje dyskursu filozoficznego. Ściśle rzecz biorąc chodzi o dwa problemy, których wspólna artykulacja pozwala „wyłapać” szczególną dynamikę myślenia w polu immanencji. Pierwsze spotkanie-perforacja ma dość prozaiczną postać pytania, które Louis Althusser zadał sobie w połowie lat siedemdziesiątych: „czy łatwo jest być marksistą w filozofii?”. Zagadnienie to wynika ze szczególnego społeczno-politycznego umocowania filozofii jako dyskursu operującego na sprzecznościach i napięciach ideologicznych aparatów państwa, które w polu filozofii podlegają unifikującej pracy pojęcia. Dyskurs filozoficzny był dla Althussera ściśle związany ze strukturami państwa i klasową naturą stosunków społecznych, zaś stanowisko marksistowskie rozumiane było jako polityczna interwencja, kij włożony w szprychy teorii, która zaciera swoje własne materialne uwarunkowania, skrywając za uniwersalizującym pozorem pozycyjny partykularyzm. Z tej perspektywy marksizm jawi się jako obce ciało na gruncie dyskursu filozoficznego, które pozwala powiązać ten dyskurs z materialnymi warunkami, w których się on dokonuje. Innymi słowy filozoficzne stanowisko marksistowskie stanowiło dla Althussera pewne urządzenie, za pomocą którego filozofia konfrontuje się ze swoim zewnętrzem na nieswoich warunkach. Pierwszym punktem orientacyjnym jest więc dla mnie uznanie materialistycznie rozumianego zewnętrza jako czegoś niedającego się podporządkować filozoficznym roszczeniom władzy suwerennej, a jednocześnie niedającego się wyegzorcyzmować - stale obecnego, choć niedopasowanego elementu. Wiąże się z tym również uznanie ścisłego związku łączącego filozofię z instytucją państwa oraz założenie możliwości umocowania się wewnątrz dyskursu filozoficznego - tak, aby związek ten stał się widoczny nie jako zagadnienie filozoficzne, lecz także jako materialny warunek istnienia filozofii jako takiej.

Drugi punkt orientacyjny dotyczy podobnej problematyki, wyrażającej się w ramach zupełnie innej pozycji i historycznej koniunktury, jaką jest post-westfalska i proto-globalna rzeczywistość Europy końca 
siedemnastego wieku. Próby myślenia granicznych momentów filozofii nie polegają tutaj na rozbiciu czy rozszczelnieniu dyskursu, lecz na rekonstrukcji jego warunków możliwości w obliczu zewnętrza, które narzuca się ciężarem swojej własnej oczywistości. Przez radykalne zewnętrze rozumiem tu nie zewnętrzność, którą można uznać za resztkę albo dopełnienie dyskursu filozoficznego (jej „właściwe” zewnętrze przyjmujące postać historycznej przygodności), lecz zewnętrze w sensie geograficzno-historycznym, dysponujące swoją własną dziejowością, polityczną aparaturą i tradycją filozoficzną, operującą w innym rejestrze kulturowych odniesień i doskonale obojętną na problemy i pytania myśli europejskiej. Istotnym, choć nie jedynym, czynnikiem wymuszającym uznanie filozoficznego zewnętrza Europy była misja jezuicka w Chinach, działająca od końca szesnastego do początku osiemnastego wieku. W poniższym tekście dużo ważniejsze jest jednak nie tyle samo zewnętrze, co moment jego internalizacji, który przybrał postać sino-spinozyzmu, czyli przekonania o bliskości, czy wręcz tożsamości, orientalnych toposów filozoficznych i nowożytnego monizmu, którego najpełniejszym wyrazem była filozofia Spinozy (Janik 2020).

Pod koniec siedemnastego wieku dość powszechne przekonanie o istnieniu „spinozyzmu przed Spinozą” (tzn. nurtów naturalistycznych i panteistycznych) zyskało nowy, geograficzny wymiar, gdy myśl autora Etyki została powiązana z filozofią chińską. Dyskurs, który do tej pory postrzegany był jako w najlepszym wypadku radykalne skrzydło kartezjanizmu, częściej zaś jako marginalna i absurdalna tendencja w ramach filozoficznej heterodoksji, zyskał nagle polityczną artykulację, wspartą potęgą wschodnioazjatyckiego imperium (Tatián 2014). Uwaga, jaką poświęcam poniżej kosmicznemu horrorowi, w kontekście lęków dochodzących do głosu w ramach krytyki monizmu, wynika z bezpośrednich implikacji tego powiązania spinozyzmu i nowożytnego orientalizmu. Spinozyzm, podobnie jak filozofia chińska, często więc opisywany jest jako monstrum, lub za pomocą obrazów ilustrujących groteskowy świat na opak, jako inne, przenicowane myślenie, inna ontologia polityczna i inny porządek przyczynowo-skutkowy. We wnętrzu europejskiej myśli nowożytnej rozrasta się więc obce ciało, idea, która niczym kwas rozpuszcza najtrwalsze nawet i najbardziej solidne fundamenty myślenia, a wręcz podważa możliwość specyficznie ludzkiej (tzn. jednostkowej i suwerennej) egzystencji.

Należy podkreślić, że przyjęta tutaj perspektywa w żadnym sensie nie jest nowa i wpisuje się w szerszy nurt problemów poruszanych przez autorki i autorów związanych z Praktyką Teoretyczna. Na związki spinozyzmu i marksizmu, zwłaszcza w kontekście kluczowego w poniższym 
tekście uwikłania nowoczesnej podmiotowości w procesy akumulacji pierwotnej, zwrócili uwagę Jakub Krzeski i Anna Piekarska (Krzeski i Piekarska 2017). Kwestia zewnętrza, ujmowana w szerszym kontekście procesów historycznych konstytutywnych dla globalnego kapitalizmu oraz uniwersalistycznych roszczeń nowoczesności, pojawia się w pracach badaczy i badaczek zajmujących się marksowską koncepcją dóbr wspólnych (Moll 2017). Nie brakuje również ujęć genealogicznych, pokazujących, w jaki sposób płaszczyzna immanencji organizuje i przekształca od wewnątrz europejski dyskurs filozoficzny co najmniej od czasów późnego średniowiecza (Pospiszyl 2016). Coraz wyraźniejsza jest też krytyka statycznych i indywidualistycznych modeli teoretycznych, którym przeciwstawia się opartą na pojęciu dobra wspólnego polityczną ontologię relacji skupionej na konstytutywnych, wspólnotowych momentach produkcji wiedzy (Szadkowski i Krzeski 2019). Równie krytyczna wobec nowoczesnych kategorii podmiotowości i stabilnych, esencjalistycznych ontologii

Stawką byłoby tu więc zajęcie takiej

pozycji, z której można by podjąć się poszukiwania śladów dyskursu filozoficznego rozgrywającego

się na przecięciu,

w przejściu i formie hybrydalnej łączącej

niewspółmierne

elementy, a nie

w ramach pewnej hierarchicznej całości, w której dają się wyróżnić podmiot i przedmiot, centrum i peryferia, albo to, co źródłowe i to, co przychodzi z zewnętrz. jest perspektywa posthumanistyczna, starająca się wyjść poza procedurę kooptacji nowych figur i perspektyw, i proponująca zamiast tego sproblematyzowanie samej maszyny antropologicznej wyznaczającej granicę pomiędzy tym, co ludzkie i nieludzkie (Bednarek 2014). W tak rozumiany kontekst rozmontowywania relacji wnętrze-zewnętrzne wpisują się również poszukiwania nowych płaszczyzn solidarności przekraczających kluczowe dla nowoczesności oraz kapitalistycznych form wyzysku dystynkcje na to, co ludzkie i nie ludzkie w kontekście zwierzęcym czy roślinnym (Kowalczyk 2014; Bednarek 2018).

Poniższy tekst nie idzie tak daleko, jak przywołane powyżej autorki i autorzy. Jest on raczej próbą wybadania gruntu, na którym dopiero w kolejnym kroku możliwe byłoby podobnego rodzaju przejście od dyskursu większego, jakim jest w tym przypadku współczesna filozofia porównawcza oraz jej historyczne umocowanie w nowożytnej recepcji fenomenu globalności (stanowiącego wyobrażeniowy wyraz imperialnego podboju i kolonialnej ekspansji), do dyskursu mniejszego, jakim mogłaby się stać filozofia przygodnego spotkania, przyjmującego za podstawę wspólnotowy i immanentny charakter istnienia. Przejście takie łatwo więc pomyśleć jako ruch od imperialnej epistemologii, klasyfikującej i dyscyplinującej swój przedmiot, do ontologii dóbr wspólnych, w ramach której każdy pojedynczy byt ujawnia się jako plątanina swoich powiązań, przyczyn i skutków. Innymi słowy chodzi tutaj o przejście od filozofii, która porównuje, do filozofii, która sabotuje proces grodzenia, stanowiący warunek możliwości wszelkiej perspektywy porównawczej. Stawką byłoby tu więc zajęcie takiej pozycji, z której można by podjąć się poszukiwania śladów dyskursu filozoficznego rozgrywającego się na przecięciu, w przej- 
ściu i formie hybrydalnej łączącej niewspółmierne elementy, a nie w ramach pewnej hierarchicznej całości, w której dają się wyróżnić podmiot i przedmiot, centrum i peryferia, albo to, co źródłowe i to, co przychodzi z zewnętrz.

\section{Nowoczesne ramy filozofii porównawczej}

Na przełomie siedemnastego i osiemnastego wieku popularnym przedmiotem dociekań wśród autorów zainteresowanych Chinami jest problem przekładalności. Zagadnienie to zajmuje zarówno czołowe postaci europejskiej sceny filozoficznej, jak Athanasius Kircher czy Gottfried Leibniz, jak i samozwańczych specjalistów, których mnemotechniczne wynalazki mają rzekomo przekształcać skomplikowaną pracę hermeneutyczną w niemal automatyczny proces, umożliwiający wgląd w znaczenie dowolnego tekstu chińskiego (zob. Mungello 1989, 211-215). Dociekania te stanowiły szczególny wariant badań nad ideą języka powszechnego, który umożliwiałby rozstrzyganie sporów religijnych i filozoficznych w sposób niepozostawiający miejsca na niejasności. Język taki, opierając się na prawidłach rozumu, wspólnych całej ludzkości, gwarantowałby, przy zastosowaniu odpowiedniej metody, pewność sądu, niezależną od partykularnego kontekstu, w której go wydano. Dość łatwo zauważyć, że leżąca u podstaw tych poszukiwań zasada ekwiwalencji przypomina wymianę towarową, która również wymaga terminu średniego, stanowiącego wspólną miarę dla nieprzebranego bogactwa produktów, dających się odnieść do siebie nawzajem dzięki pośrednictwu pieniądza oraz globalnego rynku, integrującego regionalne sieci wymiany w jedną wielką maszynę translacyjną (Lezra 2019). Merkantylne rozumienie toczącej się za sprawą misji jezuickiej w Chinach wymiany intelektualnej dobrze wyraża słynna formuła Leibniza, który uzasadnia swoje zainteresowanie Azją Wschodnią, pisząc o „handlu światłem, który za jednym razem może dać nam wiele tysięcy lat ich pracy udostępniając im naszą własną i podwajając by tak rzec prawdziwe bogactwo jednych i drugich" (Perkins 2004 , 42). Pomimo zapewnień o wzajemnych korzyściach, wizja ta jest umocowana w eurocentrycznym uniwersalizmie, za którym skrywa się fantazja o równej wymianie pomiędzy dwoma podmiotami, dzielącymi nie tylko wspólną miarę, lecz również pragnienie, które zaspokoić może udział w globalnym systemie handlu. Intelektualne dziedzictwo Chin i Europy było przedmiotem cyrkulacji, podobnie jak południowoamerykańskie srebro i afrykańscy niewolnicy, jednak motywem napędzającym tę „wymianę” była chrystianizacja Azji, niemożliwa bez wspólnego języka 
i aparatu pojęciowego, w którym chiński mandaryn mógłby rozpoznać znane motywy, tak jak jezuicki misjonarz odnajdywał ślady pierwotnej religijności w Księdze przemian.

Współczesna filozofia porównawcza jest w znacznej mierze dziedziczką tego dyskursu, który powstaje na styku nowożytnych poszukiwań uniwersalnej ramy myślenia oraz produkcji teologicznego i filozoficznego słownika, obsługującego misjonarski projekt ewangelizacyjny w Azji wschodniej, zainicjowany przez zakon Jezuitów, a kontynuowany w osiemnastym i dziewiętnastym stuleciu przez misje protestanckie (Moeller 2018). W wymiarze historycznym stanowi ona wyraz szczególnego rozumienia światowości jako uniwersalnej ramy interpretacyjnej, w której możliwa jest swobodna konstrukcja porównań pomiędzy koncepcjami, ideami, jak i całymi tradycjami myślenia, nałożonymi na siatkę zachodniej problematyki filozoficznej. W ramach tej perspektywy, podobnie jak w przypadku wymiany towarowej, dzieje świata wziętego jako całość przyjmują jeden partykularny kontekst, czyli nowoczesne dzieje Zachodu, jako miarę i ramę znaczeniową, do której dostrajane są inne czasowości wraz z właściwym im sposobem filozoficznej konceptualizacji. Normatywne ramy tej formy światowości wymagają zarówno aparatów gwarantujących jej materialną reprodukcję, jak i podejmowanych nieprzerwanie przekładów partykularnego kontekstu na język globalnej całości.

Rebecca E. Karl zwróciła uwagę na tę potrzebę ciągłego powtarzania wysiłku interpretacyjnego, pozwalającego wyjaśnić stosunek danego regionu do historii, analizując dwudziestowieczne recepcje zachodniej ekonomii politycznej w Chinach w okresie republikańskim i po śmierci Mao Zedonga. Jak pokazuje Karl, stawką autorefleksyjnej konfrontacji z uniwersalistycznymi roszczeniami zachodu była odpowiedź na pytanie, w jaki sposób możliwe jest pomyślenie szczególnego usytuowania Chin w globalnym porządku inaczej, niż przez dialektykę normy i wyjątku, dla której osią jest globalny rozwój kapitalizmu (Karl 2017). Zmieniająca się pozycja Chin zarówno w wymiarze geopolitycznym jak i w ramach globalnego podziału pracy wiąże się z ciągłym redefiniowaniem „przypadku Chin”, rozumianego już to jako typowy rezultat imperialistycznej ekspansji, już to jako wyjątek wyjaśniający „orientalne” zapóźnienie w stosunku do historii Zachodu, już to jako nowy wzorzec dla procesów modernizacyjnych (Karl 2017).Współczesna filozofia porównawcza jest w znacznej mierze wytworem tej samej dialektyki, uwikłanej w zuniwersalizowaną pojęciowość zachodniego idiomu, pozwalającą interpretować dowolne zagadnienie przez pryzmat tożsamości i różnicy, których gra zmienia światowe dzieje filozofii w rezerwuar interesujących punktów 
widzenia i nowych rozwiązań dla starych problemów filozoficznych (patrz Silius 2020). Nawet te nurty filozofii porównawczej, które w centrum stawiają kwestię inkluzyjności i krytykę okcydentalizmu, są zaskakująco ostrożne w recepcji perspektyw, które mogłyby rozbić leżącą u jej podstaw koncepcję światowości jako z gruntu uniwersalnego i transparentnego medium, umożliwiającego swobodną grę porównań w ramach pewnego ustalonego kanonu podziałów kulturowych i historycznych, wyprowadzanych z historycznej matrycy europejskiej dziejowości ${ }^{1}$. Innymi słowy świat, w którym rozgrywa się współczesna komparatystyka filozoficzna pozostaje ukonstytuowany przez globalną abstrakcję ekonomii politycznej, w której pewne socjoekonomiczne całości, skrystalizowane pod postacią państw narodowych, rozwijają się wzdłuż ujmowanej w kategoriach rozwojowych osi czasu.

Historycznie rzecz biorąc domknięcie tych całości oraz ich uzgodnienie $\mathrm{z}$ antropologiczną i spekulatywną siatką pojęciową dokonuje się na przełomie osiemnastego i dziewiętnastego wieku, kiedy z jednej strony Adam Smith dopracowuje swoją teorię stopni rozwoju opartą na sposobach wytwarzania wartości (Meek 2011, 5-36), a z drugiej niemiecki idealizm kreśli kontury światowej historii filozofii jako procesu kulminującego w filozoficznym systemie Immanuela Kanta (Park 2013). Jednak źródła nowoczesnych europejskich studiów porównawczych sięgają znacznie dalej, do wieku szesnastego, gdy myśl scholastyczna zostaje skonfrontowana z kolonialnym podbojem Ameryki. W swoim głośnym studium szesnastowiecznych etnografii, pisanych przez autorów skupionych wokół uniwersytetu w Salamance, Anthony Pagden pokazuje, w jaki sposób potrzeba uzasadnienia politycznych roszczeń korony hiszpańskiej wobec rdzennej ludności amerykańskiej zaowocowała całą taksonomią cywilizacji i kultur opartą na arystotelesowskiej psychologii. Wśród autorów tworzących nowy język moralnej antropologii, takich jak Francisco de Vitoria, Bartolome Las Casas czy Jose de Acosta, dominowało przekonanie o nieadekwatności koncepcji naturalnego niewolnictwa do wyjaśnienia kolonialnego panowania, którego ideologiczną podstawą pozostawała chrystianizacja. Z dzikiego niewolnika, skazanego

1 Dobrym przykładem jest opublikowana w 2018 roku książka Bryana Van Nordena, Taking Back Philosophy (Norden 2017), programowy manifest postulujący reformę zachodnich ( $\mathrm{tj}$. anglosaskich) studiów filozoficznych polegającą na włączeniu do programu nauczania „niedoreprezentowanych” nurtów intelektualnych i mniejszościowych perspektyw teoretycznych. Ostatecznie jednak zarówno problematyka badawcza, jak i kontekst porównawczy tak rozumianych studiów obliczone są raczej na ubogacenie zachodniej problematyki filozoficznej niż jej transformację. 
na wieczny stan poddaństwa, ludność Ameryki zmienia się w szesnastym wieku w barbarzyńskiego nieszczęśnika: jego kondycję cechuje dziecięcy niedorozwój, z którego wyjść pozwoli dopiero opieka chrześcijańskich władców, biorących na swoje barki misję cywilizacyjną i ewangelizacyjną, której stawką jest ostatecznie wprowadzenie całej ludzkości do królestwa bożego (Pagden 1986, 29).

Nie bez znaczenia jest tutaj fakt, że ów zdziecinniały dzikus zamieszkiwał nie tylko zamorskie kolonie, lecz również dolne żerdzie społecznej drabiny w krajach europejskich. Jak przekonuje Pagden, teologiczne traktaty pełne są wzmianek o „naszych” Indianach z Sewilii, Sycylii czy Asturii (Pagden 1986, 97-98). Amerykański Indianin wymagał opieki i władczej ręki pana z tego samego powodu, dla którego potrzebował jej mówiący własnym dialektem europejski chłop, w opinii teologów „niewiele różniący od dzikiego zwierzęcia” (Pagden 1986, 97). Obraz barbarzyństwa jako nienowoczesnej kondycji ludzkiej istniejącej nie na zewnątrz, lecz pod powierzchnią czy też w trzewiach ciała społecznego, pojawia się więc w nowożytnym dyskursie filozoficznym, zanim jeszcze na dobre ugruntowane zostało pojęcie Zachodu, krystalizujące się w toku coraz bardziej intensywnych kontaktów Europy z Azją Wschodnią w siedemnastym stuleciu.

\section{Świat jako zwierciadlany zasób}

Szczególnego rodzaju dyspozycja autorów siedemnastowiecznych względem historycznego i geograficznego zewnętrza filozofii europejskiej wyraża się zwłaszcza w nowym sposobie pojmowania świata, uznawanego implicite za całość, stanowiącą podstawę mnożących się zestawień i porównań. Warto skontrastować ten rodzaj światowości z obrazem zawartym w jednej z najsłynniejszych relacji podróżniczych późnośredniowiecznej Europy, Opisaniem świata, autorstwa Marco Polo. Tekst tego dzieła powstał około 1299 roku w wyniku współpracy z Rusticellem, zawodowym autorem powieści arturiańskich, którego Marco Polo poznał w genueńskim więzieniu. Dość powszechnie przyjmuje się, że obraz Azji dominujący w Europie od końca trzynastego wieku do czasów nowożytnych został w znacznej mierze ukształtowany właśnie przez fakt, iż relacja weneckiego kupca została zręcznie wpleciona w świat rycerskich romansów. Historycznie rzecz biorąc, sam świat opisany był dość kruchym historycznie tworem, powstałym na skutek podboju mongolskiego, który drastycznie przekształcił polityczną mapę Azji. Jedną z bezpośrednich konsekwencji pax mongolica było otwarcie względnie bezpiecznych 
szlaków handlowych: niemal całą trasę z Akry do Kambałyku (dzisiejszy Pekin) Marco Polo pokonał lądem, co rzutuje na szczególnego rodzaju monotonną fragmentaryczność relacji, w której świat zawsze jawi jako najbliższe otoczenie:

Gdy wyjedzie się z wymienionego miasta [Balk], podróżuje się jeszcze przez dwanaście dni w kierunku wschodnim i północno-wschodnim, nie zachodząc żadnego osiedla, gdyż mieszkańcy wszyscy uszli w góry i w niedostępne ustronia z obawy przed plądrowaniem zbójów i wojsk bezustannie tamtędy przeciąganych (...). Po upływie tych dni dwunastu spotyka się gród zwany Tajkan, gdzie jest wielki targ na zboże. (...). Gdy z tego miasta jedzie się dalej w kierunku północnowschodnim i wschodnim, podróżuje się przez trzy dni krajem pięknym, dobrze zaludnionym, bogatym w owoce, zboże i winnice (...). O trzy dni drogi stamtąd spotyka się miasto zwane Skasem, podległe jednemu księciu, który posiada inne miasta i zamki w górach (Marco Polo 1975, 113-114).

Tylko retrospektywna siła opisu jest w stanie nanizać poszczególne krainy na wiążący je w jedną całość narracyjny sznur. Jednocząca siła aparatu państwowego jest ledwie obecna i krucha ${ }^{2}$. Nawet Chiny pod panowaniem Kubilaja, mongolskiego założyciela dynastii Yuan, są przede wszystkim dziesiątkiem miejsc oddalonych od siebie o dystans, do którego pokonania potrzeba przynajmniej kilku dni. Świat lądowy jest więc zawsze konkretnym miejscem, które istnieje w diachronicznym porządku podróży - „trzy dni drogi na północny wschód”, „o trzy dni drogi stamtąd”. Oczywiście każda z tych zdesynchronizowanych krain ma również właściwą sobie wewnętrzną charakterystykę. Wiele miejsc pustoszeje i odżywa w rytm piaskowych burz i wojennych najazdów, inne cechują się niebywałą żywotnością, związaną z bliskością szlaków handlowych lub szczególną urodzajnością ziemi, jednak to lokalnie doświadczany czas jest podstawowym narzędziem opisu, pozwalającym odnieść je do siebie nawzajem.

W siedemnastym wieku taka lądowa perspektywa jest nadal możliwa, chociaż osadzona jest w świecie, który istnieje jako całość złożona ze współczesnych sobie elementów. Około 1602 roku Bento de Gois wyru-

2 Obraz Azji wyłaniający się z Opisania świata dość silnie rezonuje z ustaleniami antropologów krytycznych wobec skoncentrowanego na państwie obrazu przednowoczesnej historii. Jak przekonuje James Scott, przynajmniej do połowy szesnastego wieku państwowość była zjawiskiem łączącym ze sobą raczej pojedyncze punkty otoczone trudnym do przebycia i niemal niemożliwym do rządzenia terenem, zamieszkanym przez uciekinierów i wspólnoty, których instytucje polityczne cechował często silnie antypaństwowy charakter (Scott 2010).

Oczywiście każda z tych zdesynchronizowanych krain ma również właściwą sobie wewnętrzną charakterystykę. Wiele miejsc pustoszeje i odżywa w rytm piaskowych burz i wojennych najazdów, inne cechują się niebywałą żywotnością, związaną z bliskością szlaków handlowych lub szczególną urodzajnością ziemi, jednak to lokalnie doświadczany czas jest podstawowym narzędziem opisu, pozwalającym odnieść je do siebie nawzajem. 
sza z Indii do Pekinu; obiera drogę lądową, chcąc dowieść, że Chiny, gdzie od dwudziestu lat działa misja jezuicka, są w istocie tym samym miejscem, co opisywany przez Marco Polo Kataj; świat jest historyczną i geograficzną jednością, a rolą terytorium jest potwierdzenie mapy. Również w siedemnastowiecznej filozofii pojawia się globalny horyzont, którego najbardziej namacalnym śladem jest bogactwo egzotycznych anegdot, porównań i ilustracji. Jednak jedno z najgłośniejszych światowych wydarzeń, które w tym okresie wzbudziły żywą reakcję filozofów, miało kosmiczny, a nie ziemski charakter. W 1680 roku na północnym niebie pojawiła się kometa. Przez wiele dni była widoczna gołym okiem, a z pomocą teleskopu mogła być obserwowana jeszcze w marcu 1681 roku. Już w listopadzie 1680 roku zauważył ją niemiecki astronom Gottfried Kirch, jednak wzmianki o niej znajdujemy również w chińskich annałach historycznych (Peng-Yoke i Tian-Se 1970) czy w wierszach, których autorem jest hinduski poeta Samarth Ramdas (Kapoor 2018). W Meksyku, rok po przelocie komety, Carlos de Sigüenza y Góngora wydał dziełko Manifesto Philosofico contra los cometas despojados del imperio que tenian sobre los timidos, dowodzące, że, wbrew powszechnemu przekonaniu, komety nie posiadają istotnego wpływu na ludzki los. Niedługo później, również w Meksyku, ukazał się opis trajektorii komety autorstwa Eusebia Kino (1645-1711), który wcześniej obserwował ją w Cadiz, mieście położonym u wybrzeży Gibraltaru. Przelot komety stał się też kanwą rozprawy Pierra Bayle’a, stanowiącej doskonały przykład filozoficznej geografii biorącej świat za daną i poręczną całość. Jego Pensées diverses sur la comète ukazują się w 1682 roku jako jeden z fundacyjnych tekstów racjonalistycznego sceptycyzmu.

Bayle, podobnie jak Carlos de Sigüenza, przekonywał, że kometa nie ma wpływu na ludzki los, zwłaszcza zaś nie może być traktowana jak omen katastrof i tragedii ${ }^{3}$. Rozprawa stanowiła także formacyjny tekst dla projektu filozoficznego, który Bayle rozwijać będzie przez resztę życia,

3 Poglądy na temat pochodzenia komety i jej wpływu na ludzkie losy były zróżnicowane, często jednak były wyrazem powszechnego poglądu o tym, że niecodzienne wydarzenia i kataklizmy, podobnie jak potwory, stanowią łącznik pomiędzy światem naturalnym i nadnaturalnym (K. Park i Daston 1981). Nie brakowało jednak naturalistycznych wyjaśnień. Jeden z interlokutorów Góngori, Jose Escobar Salmeron, bronił stanowiska, zgodnie z którym komety były skondensowanymi wyziewami potu i tchnień wydawanych przez umierających. Athanasius Kircher, jeden z największych siedemnastowiecznych erudytów, głosił podobny, choć mniej spektakularny pogląd, wedle którego komety były skutkiem parowania (ku takiemu wnioskowi skłaniał się również Kino). Z takimi poglądami polemizował między innymi Tychon Brahe, przekonując, że komety powstają na znacznych wysokościach, daleko poza sferą podksiężycową (patrz Shaffer 1952). 
skupionego na poszukiwaniach racjonalistycznego umocowania dla nowożytnych instytucji politycznych. Po raz pierwszy pojawia się w nim między innymi sugestia, że możliwe jest społeczeństwo ateistów, wiodących moralny żywot bez potrzeby uciekania się do prawdy objawionej. Hipoteza ta wyłania się z gęstej siatki anegdotycznych wzmianek i wyimków z dzieł podróżniczych. Należy jednak podkreślić, że ateizm był pod koniec siedemnastego wieku bardzo pojemnym określeniem, rozumianym raczej jako konsekwencja naturalizmu, bez względu na to, czy przyjmuje on postać religijnego mistycyzmu, czy materializmu. Dlatego też nie jest niczym zaskakującym, że w rozdziale poświęconym pytaniu o to, czy można posiadać ideę przyzwoitości nie wierząc w Boga, Bayle wpisuje ateistyczną kondycję moralną w horyzont immanencji, ilustrując ją eklektyczną mozaiką skomponowaną z fragmentów żywotu sufickiej mistyczki Rabii al-Adawiji, saducejskiej teologii doczesności oraz epikureizmu:

[A]mbasador św. Ludwika na dworze sułtana Damaszku, spytawszy kobiety, którą spotkał na ulicy, co też miała na myśli, niosąc ze sobą ogień w jednej oraz wodę w drugiej dłoni, dowiedział się od niej, że zamierzała ona spalić raj ogniem i ugasić piekielne płomienie wodą, tak by ludzie nie służyli już więcej bogu kierując się zyskiem, lecz wyłącznie z racji doskonałości jego natury. Nie wspominając już nawet o Saduceuszach, którzy zajmowali się służbą Bogu, chociaż nie spodziewali się oni odeń niczego poza dobrami tego życia, czyż nie czytamy, że Epikur, który zaprzeczał opatrzności i nieśmiertelności duszy, nie zaprzestał oddawania czci Bogom? (Bayle 2000, 221)

Świat Pensées diverses... jest nie tylko geograficzną, ale i historyczną całością, w której każdy lokalny kontekst można przetłumaczyć na inny, bliższy i lepiej znany. Bayle zestawia ze sobą więc pogański ikonoklazm po śmierci Germanikusa z biurokratyczną teologią regulującą życie bóstw na cesarskim dworze w Japonii, tworzy hipotetyczne spotkania między jezuickimi misjonarzami a cesarzem Chin, i odwraca perspektywę, zastanawiając się nad reakcją europejskich dworów, których kraj stałby się nagle przedmiotem kolonialnej działalności misyjnej (Charnley 1990). Te nieoczywiste i często zaskakujące powiązania i odwrócenia znajdują oparcie w ogólnoludzkiej teorii uczuć moralnych, pozwalającej wpisać konkretną historyczną problematykę w uniwersalny horyzont ludzkiej natury, w ramach której namiętności mają sprawczość nie mniejszą niż rozum. Stawką tej argumentacji jest relatywizacja uniwersalistycznych roszczeń chrześcijaństwa (zwłaszcza katolicyzmu) jako doktryny zgłaszającej pretensje do moralnej podbudowy europejskiego życia społecz- 
nego. Zdaniem Bayle'a nakazy moralne i prawa nie znajdują umocowania w racjonalności, ale tym bardziej nie dają się wywieść z objawienia. W tym sensie dwie główne stawki projektu filozoficznego Bayle’a obrona tolerancji religijnej i sceptycyzm - są ze sobą ściśle powiązane jako wyraz filozoficznej antropologii wolnej od teologicznych naleciałości. Człowiek niezależnie od kontekstu kulturowego podlega tym samym pobudzeniom i kieruje się tym samym naturalnym prawem, którego osią jest samozachowanie.

Materialny warunek możliwości tak rozpisanej antropologii filozoficznej, jak i perspektywy porównawczej przyjętej przez Bayle’a, stanowi struktura bardziej namacalna niż ludzka natura. Kiedy spojrzymy na źródła, z których korzysta Bayle w rozprawie o komecie, zorientujemy się, że jedność świata rozświetlanego kosmicznym blaskiem komety jest w istocie patchworkiem relacji podróżniczych, z których wyłania się obraz świata zapośredniczonego w marynistycznej geografii, operującej masywnymi i uogólnionymi kategoriami lądu i morza, w których całość poprzedza część. Teksty te stanowią główne źródło informacji o świecie ulokowanym poza Europą i okolicami basenu Morza Śródziemnego. Za pośrednictwem relacji z miejsc w przeważającej mierze położonych na trasie lub u kresu morskiej podróży, myśl nowożytna zaczyna rozpoznawać swoje globalne usytuowanie, które - inaczej niż w przypadku mozolnego marszu Marco Polo - konstytuuje się na płaszczyźnie gładkiej, morskiej przestrzeni. Rozpoznanie to jest jednak raczej wyrazem zwierciadlanej relacji niż konfrontacji z innością. W siedemnastym wieku dystans dzielący Azję i Europę nadal wymaga długiej i niebezpiecznej podróży, jednak system portów i faktorii zmienia obcy świat w sieć znajomych punktów, które, niczym układ soczewek i luster odbijają, załamują i rozprowadzają obraz „Zachodu”. Nie powinno więc zaskakiwać, że filozofia doby nowożytnej często czyni użytek z tego zwierciadła: Bayle, Malebranche, a nawet Leibniz korzystają z orientalnego ekranu, na którym odbijają się główne tematy europejskich debat.

Jednak ówczesna kulturowa optyka nadal ustępuje pod względem sprawności potężnemu systemu imperialnych zwierciadeł, które w kolejnym stuleciu zmienią świat w serię doskonale wygładzonych powierzchni. Zwłaszcza Azja południowo-wschodnia jest miejscem, w którym europejska obecność jest często warunkowa i ledwie tolerowana. Kiedy po początkowych sukcesach ewangelizacyjnych w Japonii Franciszek Ksawery rozpoczyna zabiegi zmierzające do ustanowienia misji w Chinach, szybko okazuje się to zadaniem bardzo trudnym. Ostatecznie w 1583 roku Matteo Ricci i Michele Rugierii zyskują pozwolenie na osiedlenie się w Kantonie (dzisiejsza prowincja Guangdong), gdzie początkowo żyją 
goląc głowy i nosząc się na sposób buddyjskich bonzów, by po kilku latach przywdziać stroje konfucjańskich uczonych. Nawet po zapewnieniu sobie stosunkowo bezpiecznej pozycji na cesarskim dworze, jezuici muszą stale nawigować pomiędzy zwalczającymi się stronnictwami politycznymi, zawierając kruche sojusze i negocjując uzgodnienia między chrześcijańską teologią a chińskimi tekstami kanonicznymi (por. Gernet 1973). Z tych negocjacji wyłania się dyskursywna hybryda, będąca rezultatem licznych, często wymuszonych, zabiegów translacyjnych, asymilacji pojęciowych i strategii interpretacyjnych, zmierzających do wpisania tradycji konfucjańskiej w pojęciowe ramy scholastyki ${ }^{4}$. Bayle będzie jednym z pierwszych autorów, którzy zajrzą pod spód tej bogato zdobionej egzotycznymi anegdotami misjonarskiej opowieści, odkrywając grube, poskręcane szwy monistycznego monstrum, na którego ciele wznosi się obraz Konfucjusza, urobionego na modłę chrześcijańskich świętych ${ }^{5}$. Za sprawą popularności tekstów Bayle’a monizm, a więc pogląd filozoficzny, zgodnie z którym istnieje jedna tylko substancja, a byt jednostkowy jest w najlepszym przypadku jej modyfikacją, w najgorszym zaś iluzją, zostanie wyniesiony do rangi filozofii dominującej w świecie azjatyckim i przenikającej równocześnie filozoficzny dyskurs europejski. Katalizatorem wyprowadzenia genealogii monizmu poza kontekst europejski były jednak jezuickie sinografie, które w siedemnastym wieku stanowią niemal jedyne źródło recepcji filozofii chińskiej w Europie.

\section{Monistyczne monstrum}

Ważną rolę w kształtowaniu się nieeuropejskiej genealogii monizmu odgrywała zwłaszcza jezuicka interpretacja tradycji neokonfucjańskiej, w której splatały się ze sobą teksty kanoniczne oraz buddyjska i tao-

4 Brak tutaj miejsca na bardziej szczegółowe omówienie jezuickiej działalności misyjnej w Chinach. Warto jednak zaznaczyć, że jezuici dość wyraźnie odgraniczali taoizm i buddyzm od utożsamianego z konfucjanizmem chińskiego dyskursu filozoficznego. Ten ostatni rozumiany był jako pewien splot praktyk teoretycznych $\mathrm{i}$ instytucji politycznych, uznających za swoje naturalne umocowanie porządek państwowy. Jest to istotne ze względu na fakt, że mniej więcej od drugiej połowy siedemnastego wieku Chiny w coraz mniejszym stopniu traktowane są jako domena działań ewangelizacyjnych, a w coraz większym stopniu postrzegane jako podmiot w porządku międzynarodowym usytuowany vis-à-vis państw europejskich.

5 Lionel Jensen stawia tezę, że konfucjanizm rozumiany jako zindywidualizowany kult Konfucjusza jest niemal w całości wytworem misji jezuickiej w Chinach (zob. Jensen 1997). 
istyczna pojęciowość. Eklektyzm cechujący autorów konfucjańskiego odrodzenia w okresie dynastii Song, takich jak Zhou Dun Yi czy Zhang Zai, był kłopotliwy dla misjonarzy, szukających punktu zaczepienia dla działalności ewangelizacyjnej raczej w wydestylowanej doktrynie moralnej wiązanej z postacią Konfucjusza niż w spektakularnej metafizyce neokonfucjańskiej, wychodzącej od deklaracji faktycznej jedności przenikającej i łączącej ze sobą każdy byt poszczególny. W tekstach jezuickich neokonfucjańska wizja świata rozumianego jako zróżnicowana ekspresja pewnej kosmo-ontologicznej wspólnoty, zyskała monstrualne cechy jako doktryna narosła zdaniem misjonarzy na koncepcji wszechogarniającego i polimorficznego ciała natury, wykluczającej jakąkolwiek transcendencję, a tym samym niepozwalającej choćby pomyśleć sensownej idei Stworzenia, czy transcendentnego Boga. Pomimo dominującej i wspartej autorytetem Matteo Ricciego tendencji do poszukiwania w chińskich tekstach źródłowych motywów monoteistycznych oraz interpretacji obrzędowości konfucjańskiej jako świeckiej praktyki duchowej, wśród misjonarzy silny był nurt potępiający całą chińską tradycję intelektualną, jako przesiąkniętą materializmem i z gruntu ateistyczną.

Taki obraz filozofii chińskiej pojawia się między innymi w krótkim tekście Traité sur quelques points de la religion des Chinois, napisanym około 1623 lub 1624 roku przez Nicolasa Longobardiego, który stanął na czele misji po śmierci Ricciego. Zdaniem jezuity szczególnie niedostępne chińskiej pojęciowości pozostawały takie terminy jak Bóg i dusza (Longobardi 1701) ${ }^{6}$. Szukając klucza interpretacyjnego do filozofii chińskiej należy zatem za dobrą monetę wziąć zasadę, zgodnie z którą „wszystko jest jednym”, przyświecającą „nowym interpretatorom” (tj. neokonfucjanistom) i wyrażającą filozoficzne jądro myśli chińskiej. Posługując się tylko tą zasadą, przekonuje Longobardi, można dowieść, że czołowi przedstawiciele „sekty” konfucjańskiej „albo nie znają wcale

6 Główny zarzut Longobardiego dotyczył nie konfucjanizmu, lecz postulowanego przez Ricciego rozdziału komentarzy i kanonicznych tekstów konfucjańskich. Zdaniem Ricciego chrześcijaństwo byłoby przekonujące dla chińskich elit jako wehikuł pozwalający wydobyć pierwotną treść konfucjanizmu z bałwochwalczych buddyjskich rojeń. Longobardi odrzucał tę strategię, przekonany, że cała konfucjańska tradycja jest ściśle związana z neokonfucjańskim odrodzeniem, które nie tylko pozwala zrozumieć właściwą treść tych tekstów, lecz retrospektywnie ustanawia całą tradycję, której metafizyczny sens zawiera się w materialistycznie rozumianym monizmie: istnieje jedna substancjalnie pojmowana zasada, taiji, której wyrazem i realizacją jest dwubiegunowa materia pierwsza qi, posiadająca dwa stany yin i yang, tworzące w szeregu układów wielość rzeczy poszczególnych, dla których zasadą jednostkowania jest konsystencja raczej niż jakkolwiek rozumiana forma substancjalna. 
Boga, albo też znają go jako coś monstrualnego i chimerycznego - co na jedno wychodzi” (Longobardi 1701, 136). Większość egzemplarzy pamfletu Longobardiego została zniszczona w 1626 roku, po konferencji w Jiading, w trakcie której zdecydowano o kontynuacji akomodacjonistycznej strategii misyjnej. W 1701 został on jednak przełożony na język francuski i opublikowany wraz z innym anty-akomodacjonistycznym traktatem autorstwa dominikanina Antoine de Saint Marie, Traité sur quelques points importans de la mission de la Chine, jako argument w tzw. sporze o ryty chińskie. Publikacja ta zbiegła się w czasie ze szczytowym momentem zainteresowania misją jezuicką w Chinach wśród europejskiego środowiska filozoficznego. Jednym z uważnych obserwatorów tych sporów był Bayle, który rok później opublikował drugie wydanie swojego najsłynniejszego dzieła, Dictionnaire Historique et Critique, poszerzone między innymi o przypisy dotyczące związków między spinozyzmem a myślą chińską, a oparte o wyimki i opracowania z głównych sinografii jezuickich, zwłaszcza zaś Confucius sinarum philosophus (1658).

Już pierwsze wydanie słownika, opublikowane w 1697 roku, zawarło pod hasłem "Spinoza” liczne azjatyckie odniesienia, łącząc motywy zaczerpnięte $\mathrm{z}$ hinduizmu czy islamskiego mistycyzmu z poglądami chrześcijańskich heretyków i naturalistycznie zorientowanych filozofów pogańskich. W drugim wydaniu Bayle poszerzył te odniesienia o Azję wschodnią, porównując filozofię Spinozy do taoizmu i buddyzmu. Wszystkie zebrane w przypisach uwagi kilkukrotnie przekraczają długość samego hasła. Pomimo szczerego uznania dla filozoficznej zmyślności Spinozy oraz jego wielce cnotliwego trybu życia, artykuł Bayle’a przedstawia system autora Etyki jako myśl monstrualną, prowadzącą do niezliczonych absurdów, składających się na obraz świata, w którym wszystko, co poszczególne zapada się w wiecznie mutującym bożym cielsku. Według Bayle’a najbardziej skandalicznym elementem spinozjańskiego systemu jest pojęcie modyfikacji, nabudowane na monistycznej koncepcji substancji. Tłumacząc w przypisie „N”, na czym polega potworność dzieł Spinozy, Bayle przekonuje, że twierdzenie, iż człowiek jest wyłącznie modyfikacją jedynej substancji, tożsamej z Bogiem, oznacza, iż jedynym podmiotem zdolnym do działania jest Bóg, który wojuje sam z sobą, zmodyfikowany już to w Turków, już to w Węgrów. Taki pogląd „przebija wszelkie potwory i chimeryczne wypaczenia największych nawet szaleńców, zamkniętych w domach dla obłąkanych”. Monizm nie jest więc po prostu błędnym poglądem filozoficznym, lecz obłąkańczą wizją świata. Jednak prawdziwe zastanawiającą cechą tego stanowiska okazuje się jego historyczny i geograficzny zasięg. 
Bayle zaczyna swoją rekonstrukcję ateistycznej diaspory od przytoczenia wspomnianej powyżej epikurejsko-sufickiej filozofii immanencji, z tą różnicą, że tutaj ilustruje ona jego zdaniem nie ideę radykalnej doczesności, lecz monistycznej jedności z Bogiem. Bayle przytacza również pozostające na marginesie myśli europejskiej stanowiska materialistyczne i panteistyczne reprezentowane przez takich autorów, jak Straton czy Dawid z Didant ${ }^{7}$. Stosunkowo dużo miejsca poświęca również opisom monistycznych motywów w filozofii perskiej i indyjskiej, przedstawionych w relacjach podróżników Pietro de la Valli i Francois Berniera. Wszystkie one utrzymane są raczej w tonie denuncjacji, ujawniającej absurdalność i potworność świata, w którym istnieje jedna tylko substancja. Szczególnie barwny jest pod tym względem długi cytat z La Description des etats du Grand Mogol Berniera, w którym klasyczne wątki Upaniszad zostają skonfrontowane z metafizycznym idiomem zachodniej filozofii. Bernier, opisując koncepcję duszy świata, przywołuje obraz Boga-pająka, tkającego sieć rzeczywistości z własnych wnętrzności. Świat, który przenika jedna tylko dusza, referuje Bernier, jest tylko pochodną kosmicznej, pajęczej jedni, w której nie ma miejsca na realną jednostkowość rzeczy: „Nie ma, jak mówią, nic a nic rzeczywistości ani sprawczości w tym, co widzimy, czujemy, słyszymy, smakujemy, czy dotykamy; cały świat jest czymś w rodzaju snu, czystą iluzją o ile cała ta mnogość rzeczy, jawiąca się przed nami jest jedną, jedyną i tą samą rzeczą, to znaczy samym Bogiem” (Bayle 1826, III: 276-77). Całość zasysająca wszystkie swoje części i zmieniająca zmysłową rzeczywistość w iluzję zajmuje centralną pozycję w Baylowskiej krytyce systemu Spinozy, który uznany zostaje za „metodę myślenia”, rozpowszechnioną w Indiach i innych krajach Azji. Zawarta w przypisach do słownikowego hasła opowieść o monistycznej diasporze ma więc inną wymowę niż anegdotyczne ilustracje sceptycznych argumentów z Pensées diverses sur la comète. Chociaż również w tym przypadku nurt naturalistycznie zorientowanego monizmu - usytuowany dosłownie pod powierzchnią głównego tekstu - jest zlepkiem najróżniejszych tradycji i motywów rozproszonych po całym świecie, to jego funkcja zaświadcza raczej o radykalnej odmien-

7 Siedemnastowieczna filozofia była świadoma istnienia w swym obrębie nurtów panteistycznych, poruszających się w polu immanencji, rozwijanych co najmniej od czasów późnego średniowiecza (Pospiszyl 2016). Przekonanie o tym, że spinozyzm był jedynie najbardziej spektakularnym stanowiskiem w długiej historii ateizmu, nie było samo w sobie kontrowersyjne, a Baylowskie powiązanie tradycji panteistycznej z filozofią azjatycką stanowiło w gruncie rzeczy rozwinięcie wcześniejszych studiów nad historią naturalistycznie zorientowanego ateizmu (patrz Mulsow 2015, 197-198). 
ności pewnego poglądu filozoficznego niż o zasadniczej przekładalności praktyk kulturowych i wierzeń.

Przedstawiony w słowniku monistyczny świata to rzeczywistość sennego marzenia, w którym byt jednostkowy wiedzie urojone życie, będąc $\mathrm{w}$ istocie osobliwym wybrzuszeniem na ciele jedynej substancji. Bayle posługuje się całą serią plastycznych ilustracji, przekonując, że to nie człowiek jest podmiotem swych działań, lecz tożsamy z całą naturą Bóg, targany sprzecznymi afektami, których doświadcza jego wielorakie ciało. Krytyka ta rozgrywa wszystkie orientalistyczne motywy, które w późniejszym okresie staną się osią europejskiej recepcji myśli azjatyckiej. Rzeczywistość to pozór przesłaniający inną jeszcze, głębszą rzeczywistość, negatywną i pustą, w której unieważniony zostaje nie tylko byt ludzki, lecz również wszelkie podziały, wszystko, co stanowi moralno-ontyczne koordynaty znajomego życia. Ten obraz myśli wschodniej łączy się w tekście Bayle’a z wyobrażeniami monistycznego świata jako potwornego nawarstwienia cech, które są nie tylko estetyczną i moralną, lecz również ontologiczną fantasmagorią. Nie tylko orientalistyczne przypisy, lecz cały poświęcony Spinozie artykuł jest zbudowany na serii paradoksów, których zadaniem jest zilustrowanie „potworności i chimeryczności” spinozjańskiego ateizmu. Kluczowy argument dotyka jednak problemu suwerenności, dzięki której jednostkowo pojmowany podmiot działa zgodnie z własną wolą. W monistyczno-materialistycznym uniwersum Spinozy rozpada się sam wzorzec i gwarant tak rozumianego działania, czyli relacja transcendencji dzielącej Boga i stworzenie: jakakolwiek próba wyartykułowania koncepcji „niematerialnego Boga władającego wszystkim rzeczami w sposób doskonale wolny” musi „nieuchronnie doprowadzić to niedających się rozwikłać absurdów” (Bayle 1826, III: 334). Świat staje się pojedynczym bytem, dla którego myśl i rozciagłość zostają zidentyfikowane jako jedno istnienie, które działa wsobnie - zajmuje się nieprzerwanie swymi własnymi wnętrznościami.

Napięcie, którego rezultatem jest monstrualność monizmu, wynika z tego, że dla Bayle’a jako kartezjanisty substancja i jej własności są ze sobą „wewnętrznie i na wskroś zjednoczone” (Bayle 1826, III: 293), tak więc wzięte same w sobie przypadłości nie posiadają żadnej rzeczywistości, a wszystkie zmiany zachodzące w danej rzeczy są de facto zmianami substancjalnymi. Co ważniejsze, w kartezjańskiej metafizyce oddziaływania przyczynowo-skutkowe są - inaczej niż w tradycji scholastycznej - oddziaływaniami modyfikującymi pewien substancjalny układ danej rzeczy. Jeśli więc rzeczy są po prostu modyfikacjami jednej i tej samej substancji, przestają posiadać jakąkolwiek sprawczość oraz charakterystykę, ponieważ same stają się charakterystyką Boga i artykulacją boskiej 
sprawczości. Zdaniem Bayle'a - wyrażającego tutaj powszechnie przyjmowany pogląd - ,jakakolwiek nazwa nadana podmiotowi oznacza to, do czego ów podmiot odnosi się, czyli do substancji, nie zaś do przypadłości” (Bayle 1826, III: 295) . Tak więc jeśli Piotr ma wątpliwości, wątpliwości te są wątpliwościami Piotra, o ile Piotr brany jest w znaczeniu substancjalnym. Jeśli jednak Piotr jest modyfikacją Boga, wówczas po prawdzie to Bóg wątpi, jako że to on jest właściwym podmiotem, w którym zawierają się zarówno Piotr, jak i jego wątpienie (Bayle 1826, III: 295-96).

Świat monistyczny, rozpatrywany z perspektywy „systemu chrześcijańskich filozofów”, wydaje się więc, jak przekonuje Bayle, całkowicie wyprany z rzeczywistości, skoro wszystko jest prawdziwe o tyle tylko, o ile brane jest w totalności swojego istnienia. Nie dziwi zatem łatwość, z jaką Bayle utożsamia Spinozjańską substancję z zaczerpniętym z tradycji taoistycznej pojęciem negatywności, na której ufundowany jest byt, albo z buddyjską koncepcją sunyaty, absolutnej pustki, w której rozpuszczają się zarówno świat fenomenalny, jak i jego zaprzeczenie. W tym tonie utrzymany jest przypis „B”, omawiający podobieństwo między ateizmem Spinozy a „pewną chińską sektą” (tj. buddyzmem), której ezoteryczną treść stanowi ateizm wyrażający się przekonaniu, że rzeczywistość w całej swej różnorodności jest nie tylko złudzeniem, ale także wyrazem absolutnej i doskonale obojętnej pustki, wobec której jakiekolwiek działanie jest pozbawione znaczenia. Doktryna ta wzbudza oburzenie Bayle’a większe nawet niż spinozyzm, w którym nie odmawia się sprawczości przynajmniej naturze wziętej jako całość: „Jeśli czymś potwornym jest twierdzić, że rośliny, zwierzęta i ludzie są realnie jedną i tą samą rzeczą i obstawać przy twierdzeniu, że wszystkie byty poszczególne są co do zasady nierozróżnialne, to bardziej nawet potworną rzeczą jest utrzymywać, że zasada ta nie ma żadnej myśli, mocy i prawdy" (Bayle 1826, III: 280).

Jednak pomimo tej deklaracji monistyczna koncepcja sprawczości okazuje się problemem znacznie poważniejszym niż nierealność świata. Iluzoryczna natura poszczególnych aktorów nie umniejsza wcale realności samego działania - ostatecznie ma ono rzeczywiście miejsce, jednak jego podmiot jest zawsze jeden i ten sam. W konsekwencji problematyczna staje się sama idea porządku przyczynowego. Jeśli Bóg rzeczywiście był jedyną substancją, musiał nie tylko stanowić podmiot działania, lecz być również jego odbiorcą. O ile jednak boska substancja jest podmiotem każdej swej modyfikacji równocześnie, traci ona swoją wewnętrzną integralność, skoro każde obrażenie i cierpienie jest spowodowane przez Boga i równocześnie przezeń doświadczane. Zatem moni- 
styczny Bóg-Świat nie tylko „zarzyna” sam siebie w bitewnym szale, lecz również „nienawidzi siebie, prosi samego siebie o przysługi i odmawia ich sobie, prześladuje sam siebie, zabija się i pożera, obraża siebie i dokonuje na sobie samym egzekucji” (Bayle 1826, III:299). Co więcej, logika ta stosuje się również do stanów psychicznych, skoro myśl i rozciągłość są po prostu atrybutami jednej i tej samej substancji. Bóg zatem „wiesza się, rzuca w głąb kanału, nie mogąc znieść dłużej straszliwej melancholii jaka go pożera” (przypis). Za sprawą immanentnej przyczynowości sprawczej (stanowiącej oksymoron zarówno dla nowożytnego scholastyka, jak i kartezjanisty) bezbożność poglądu monistycznego osiąga zdaniem Bayle'a poziom, który wykracza poza wszystko, co utrzymywali inni ateiści, skoro nawet oni „nie posuwali się w swojej ekstrawagancji tak daleko, by stwierdzić, że gdyby Bóg istniał, nie byłby on doskonale szczęśliwy” (Bayle 1826, III: 299).

\section{Kosmiczny horror jako stanowisko filozoficzne}

Krytyka monizmu jest w znacznej mierze wyrazem sporów definiujących nowożytną metafizykę w jej polityczno-etycznym kontekście; to samo dotyczy kategorii potworności, charakteryzującej ujęcie świata jako jednego, wspólnego ciała. Na przełomie siedemnastego i osiemnastego wieku monstrualność jest coraz rzadziej opisywana jako fenomen mający związek z nadnaturalną boską interwencją, i staje się przedmiotem studiów porównawczych. Nietypowe przypadki, anomalie genetyczne i niezwykłe cechy fizyczne traktowane są raczej jako przykłady zmyślności natury, pozwalające lepiej zrozumieć mechanizm jej działania niż nośnik ukrytych znaczeń (zob. K. Park i Daston 1981). W argumentacji Bayle’a potworność jest przede wszystkim figurą negatywną, z którą skontrastowany jest obraz znajomej i przewidywalnej rzeczywistości, zorganizowanej wokół pojęcia substancji jako czegoś podzielnego. Jednak rozdęta do kosmicznej skali wizja chimerycznego Boga-potwora nie daje się zredukować do sfery kontrfaktycznej ilustracji. Na obrzeżach i marginesach zdroworozsądkowego filozoficznego konsensu wyraźnie majaczy inny świat, którego charakterystyka zawiera coś więcej niż tylko potworną anomalię, wynikającą z nagromadzenia wielu cech w jednym ciele, tak jak gdyby chodziło o syjamskie rodzeństwo lub cielę posiadające dodatkowe kończyny. Monistycznie pojmowana natura jest w swej istocie nieludzka.

Bayle jest jednym z pierwszych myślicieli doby nowożytnej próbujących zobrazować rzeczywistość, która pod koniec wieku osiemnastego, 
po kantowskim przewrocie transcendentalnym, stanie się stale obecnym motywem w myśli europejskiej: świat-w-sobie. Zdaniem Eugene Thackera wyobrażeniową (tj. dającą się pomyśleć) formą noumenalnego świata-w-sobie jest świat-bez-nas, czyli rzeczywistość, w której nie ma już ludzi. Potworność tak rozumianego świata stanowi estetyczny rezultat formy przejawiania się wypranego z jednostkowej podmiotowości świata-w-sobie, przebijającej w różnych momentach znaną i oswojoną rzeczywistość ujmowaną w ramach zdroworozsądkowej syntezy (Thacker 2011, 66). Jak przekonuje Eric Wilson, groza, będąca rezultatem takiego spotkania, stanowi przewrotną formę wzniosłości i osiąga pełnię literackiego wyrazu w kosmicznym horrorze, gatunku posługującym się najróżniejszymi formami protetycznych przedstawień potworności, mających za zadanie wychwycenie zasadniczo nieludzkiej natury wszechświata, w którym człowiek jest w najlepszym wypadku pewnym metafizycznym przypadkiem (Wilson 2016, 49-50). Jednak Bayle'owski opis potworności jest interesujący właśnie z tego powodu, że nie idzie tutaj o świat, w którym dochodzi do jakkolwiek rozumianej anihilacji specyficznie ludzkiego bytu, lecz do rozpisania go na planie immanencji.

Skutkiem tego jest wyłonienie się jednostkowości w monstrualnej skali - cieleśnie pojmowanej natury, której byt z jednej strony przekracza zdolność pojmowania jakiejkolwiek skończonej świadomości, z dru-

Skutkiem tego jest wyłonienie się jednostkowości w monstrualnej skali - cieleśnie pojmowanej natury, której byt z jednej strony przekracza zdolność pojmowania jakiejkolwiek skończonej świadomości, z drugiej zaś penetruje swoim istnieniem każdą najmniejszą nawet rzecz poszczególną.

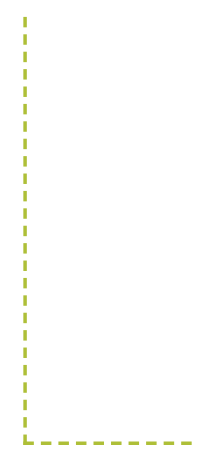
giej zaś penetruje swoim istnieniem każdą najmniejszą nawet rzecz poszczególną. Chimeryczność i gigantyzm stanowią jedne z głównych cech przedstawień potworności w horrorze, podobnie jak zmiennokształtność i nagromadzenie nieprzebranej wielości obiektów lub cech (Carroll 2003, 42-52). Chociaż brak tutaj miejsca na głębszą analizę swobody, z jaką nowożytni autorzy uciekali się do figury monstrum przy opisie stanowisk metafizycznych, to warto podkreślić, że opisy Boga jako bezkształtnej cielesności, oszalałej pod naporem wielości przeżywanych równocześnie afektów, czy przykłady ilustrujące jego zmiennokształtność, były dość powszechnie stosowanym zabiegiem; znajdujemy je zarówno w jezuickich omówieniach myśli chińskiej, utyskiwaniach arystotelików na kartezjańskie rozumienie substancji, wyjałowionej z form substancjalnych, jak i w tekstach kartezjańskich, atakujących filozofię Spinozy. We wszystkich tych opisach potworność przypisywana jest substancji pozbawionej stabilnej zasady jednostkowienia i dotkniętej przez to ciągłym rozrostem i niekończącym się nawarstwianiem kolejnych obiektów, które wyrastają jeden z drugiego, jak narośle. Chimeryczna substancja przemienia się już to w dzikie zwierzę, już to w roślinę, ten lub inny przedmiot, planetę lub formację geologiczną (Lamy 1696, 70-71; Ricci i Trigault 1617, 116). 
Pod wieloma względami opisy te bliskie są potworności, którą znajdujemy w opowiadaniach Howarda P. Lovecrafta, wśród których najbardziej znanym przedstawieniem kosmicznego monstrum jest niewielka figurka pojawiająca się w opowiadaniu Zew Cthulhu, zaprezentowana specjalistom uczestniczącym w akademickim sympozjum przez inspektora Legrasse'a:

Uczeni jęli wreszcie podawać sobie figurkę z rąk do rąk i poddawali ją starannym oględzinom. Mierzyła siedem, może osiem cali wysokości i była wytworem najprzedniejszego rękodzieła. Przedstawiała monstrum, w ogólnym pokroju jakby człekokształtne, lecz opuchłe do rozpuku, z łbem jak kałamarnica i twarzą ginącą w rojowisku macek; cielsko wydawało się gumowate i pokryte łuskami, przednie i tylnie łapy zwieńczone były potężnymi szponami, a z grzbietu wyrastały długie, wąskie skrzydła (Lovecraft 2019, 18).

Obiekt, który wzbudza zadziwienie uczonego gremium został pozyskany w wyniku obławy policyjnej, której celem było rozbicie tajemniczego kultu, praktykowanego wśród czarnych potomków piratów i niewolników na bagnach wokół Nowego Orleanu. Tak jak w większości tekstów Lovecrafta, kolor skóry i podejrzane pochodzenie traktowane są jako synonimy degeneracji i obcości, których dopełnieniem jest zeznanie, z którego wynika, że to, co początkowo brano za lokalny obrzęd voodoo (obcy, lecz dający się wyodrębnić jako przedmiot badań antropologicznych lub religioznawczych) stanowi o wiele starszą formę religijności, czy też „starożytnej sekty”, wyrosłej wokół kultu „Wielkich Przedwiecznych, którzy przybyli z nieba, gdy świat był jeszcze młody, na długo zanim narodził się człowiek" (Lovecraft 2019, 25). W tekście potworność zapośredniczona jest w formie eksponatu, zeznania, raportu, zmieniających majaczącą na granicy postrzegalności grozę w namacalne obiekty, stanowiące przedmiot specjalistycznej wiedzy, za którą stoi idea imperialnej, suwerennej władzy dającej moc dzielenia i wydzielania. Typowe dyscypliny naukowe poruszające się w dziełach Lovecrafta na styku tego, co zwyczajne i potworne składają się na katalog wiedzy-władzy, której geneza uwikłana jest w kolonialną dominację zachodu oraz rozwój instytucji nadzoru: archeologia, antropologia, językoznawstwo, kryminologia, historia sztuki, psychiatria itd. Potworność zawarta w przedmiotach i zjawiskach poddawanych skrupulatnej analizie badacza jest tutaj zapośredniczona w rozpadzie zwierciadlanej funkcji imperialnej nauki, której przedmiot przestaje mówić znanym jej językiem i zdaje się trwać w innym, obcym świecie: periodyzacje nie dają się uzgodnić z wiedzą historyczną, obiekty sztuki nie pasują do estetycznych 
kategorii, mitologie zawierają motywy nie przypominające niczego znanego z dziejów Europy.

Opisany w Baylowskim słowniku „systematyczny ateizm” Spinozy ma status podobny do zaskakująco wyrafinowanej figurki, przedstawiającej przedwieczne bóstwo - jest mistrzowsko wykonanym obiektem, pojęciowym obrazem starożytnego kultu, który istniał na długo przed tym, zanim stał się przedmiotem filozoficznych debat. Według Bayle’a przedmiotem Spinozjańskiej filozofii jest dosłownie ciało chimerycznego Boga, czczone na różne sposoby przez rozrzucone po świecie sekty i kulty, ciało opisywane przez filozofów eksperymentujących z niebezpiecznymi ideami, którego opisy znaleźć można w starożytnych księgach wschodnich mistrzów i heretyckich traktatach chrześcijańskich. Również kalejdoskop fragmentarycznych informacji, na podstawie których Bayle rekonstruuje obraz światowego monizmu, jest bardzo bliski metodzie łączenia pojedynczych faktów, depesz i zapisków, za pomocą której narrator Zewu Cthulhu odkrywa globalne zarysy kultu:

Wycinki prasowe, jak już nadmieniłem, dotyczyły przypadków paniki, manii i ekscentrycznych zachowań, które wystąpiły w rzeczonym okresie. Aby je zebrać, profesor Angell musiał zatrudnić biuro wycinków - ich liczba była bowiem olbrzymia, pochodziły zaś z najrozmaitszych zakątków świata. W Anglii pisano o nocnym samobójstwie: mieszkający samotnie londyńczyk zaniósł się znienacka rozdzierającym krzykiem i wyskoczył z okna. Gazeta z Ameryki Południowej opublikowała bełkotliwy list od fanatycznego czytelnika, który pod wpływem swych niedawnych majaków wieszczył światu rychłą zagładę. W Kalifornii pewna kolonia teozofów nagle poczęła odziewać się en masse w białe szaty z myślą o jakimś „wspaniałym spełnieniu”, które nigdy nie nadejdzie; w Indiach wzmiankowano dyplomatycznie, że w ostatnich dniach marca wśród krajowców wybuchły poważne rozruchy. $\mathrm{Na}$ Haiti mnożyły się orgie wudu. Afrykańskie faktorie donosiły, że wśród tamtejszych ludów szerzą się złowrogie szemrania. Na Filipinach o niepokojach wśród tubylców raportowali amerykańscy wojskowi; w Nowym Jorku zaś nocą z 22 na 23 marca tłum rozwydrzonych Lewantyńczyków zaatakował policjantów. Szaleńcze pogłoski i legendy szerzyły się też w zachodniej Irlandii, w Paryżu zaś na wiosennym wernisażu malarz fantasta Androis-Bonnot wystawił bluźniercze płótno Pejzaż ze snu. Problemy w przytułkach dla obłąkanych odnotowano w liczbie tak ogromnej, że chyba tylko cudem medyczne bractwo nie doszukało się w nich dziwnej zbieżności i nie zadumało nad wynikającymi z niej wnioskami. Plik wycinków tworzył całość wręcz porażającą; dziś z ledwością pojmuję, jak mogłem być tak zatwardziały w swoim racjonalizmie, by je lekceważyć (Lovecraft 2019, 16). 
Ksenofobiczny rasizm Lovecrafta znajduje ujście dzięki zapośredniczeniu monstrualności na kosmiczną skalę w obrazie spisku, noszącego wszelkie znamiona antykolonialnej rebelii przeciwko cywilizacji, ujmowanej w jej najbardziej emblematycznym, eurocentrycznym sensie: racjonalizmowi, kultowi nauki, reżimom dyscyplinarnym i imperializmowi. Jednak dużo ważniejsze wydaje się tutaj spostrzeżenie, że niepokojące doniesienia z kolonii, dziwne przedmioty i sny nawiedzające nowojorską bohemę są wyrazem i potwierdzeniem podziału na dominujący podmiot spajający i porządkujący dane doświadczenia oraz wieloraki i fragmentaryczny, lecz jednak wszechobecny, przedmiot, którego noumenalny byt nagle ujawnia się w samym środku ujarzmionej fenomenalnej przestrzeni.

Jak przekonuje Thacker, u podstaw grozy w prozie Lovecrafta leży konstatacja monistycznej natury świata: podział na to, co naturalne i nadnaturalne nie istnieje, a rzeczywistość przedwiecznych monstrów i kosmicznych ras jest po prostu innym aspektem natury, ujmowanej w skali wykraczającej poza poznawcze kompetencje ludzkiego umysłu (Thacker 2011, 77). W Zewie Cthulhu bezpośrednim tematem jest przebudzenie kosmicznego bóstwa, które nabiera charakteru zdarzenia globalnego, ponieważ, podobnie jak w spinozjańskim monizmie, jego substancja wyraża się i jest poznawana wyłącznie przez swoje pobudzenia i modyfikacje - wielcy przedwieczni wyrażają swą archaiczną moc za sprawą sennych rojeń, mrocznych kultów i niepokojów rdzennej ludności. Sama kolonialno-imperialna rzeczywistość umocowana na racjonalnej podmiotowości podziurawiona zostaje równoczesnym objawieniem się w tym samym świecie porządków, które rozdzielała i kontrolowała klasyfikacyjna gramatyka nowoczesnych dyscyplin naukowych: plemiennych obrzędów, starożytnych kultów, kosmologicznych spekulacji, nieeuklidesowych przestrzeni, kubistycznego malarstwa czy astronomicznej skali, w której miliony lat okazują się mrugnięciem oka.

Oczywiście, Lovecrafta i Bayle’a dzieli przepaść związana z ukonstytuowaniem się nowoczesnego pojęcia podmiotowości, opierającej warunki możliwości wszelkiego doświadczenia na transcendentalnej anatomii czystego rozumu. Jak zauważa Eric Wilson, groza kosmicznego horroru jest u Lovecrafta wyrazem tyleż narcystycznego ujęcia nowoczesnego doświadczenia alienacji, co formą wzniosłości uformowaną zgodnie z regułami kantowskiej estetyki (Wilson 2016, 47-50). Bayle pisze w zupełnie innej rzeczywistości. Jest autorem pokolenia, które cały czas tkwi w traumie wojny trzydziestoletniej, poszukującym wyjścia z impasu religijnych konfliktów - racjonalizm filozofii kartezjańskiej jest raczej desperacką próbą odzyskania jedności doświadczenia poprzez akt porzu- 
cenia ambicji politycznych niż (jak u Lovecrafta) lękiem przed utratą kontroli. Również orientalizm Bayle’a jest daleki od aroganckiego zadziwienia nowoczesnego badacza, ufnego wobec podstawowych parametrów ujarzmionej rzeczywistości, która niespodziewanie wybucha mu w twarz. Jednak proponowana przezeń egzotyzacja spinozyzmu przebiega wzdłuż tych samych linii, dzielących europejski świat filozoficznego konsensusu i zdrowego rozsądku oraz podskórny nurt groteskowych i szaleńczych poglądów, w ramach wciąż jeszcze dość niepewnego, choć już wyraźnie

Sam termin „parapolityka" pochodzi ze studiów nad bezpieczeństwem publicznym i odnosi się do splotu państwowości i działal-

ności przestępczej, a szerzej do pozapolitycznych źródeł władzy

politycznej oraz związków państwowych

i pozapaństwowych aktorów. widocznego globalnego horyzontu. Kiedy kilkadziesiąt lat później Hegel będzie referował poglądy Spinozy, orientalny charakter jego monistycznej filozofii będzie już rzeczą oczywistą, podobnie jak oczywista będzie swoistość tego, co w dziejach filozofii specyficznie zachodnie (już bez cudzysłowu), czyli koncepcja jednostkowości.

Nieco inną perspektywę na kosmiczny horror proponuje wspomniany przed chwilą Eric Wilson, gdy czyta prozę Lovecrafta jako narzędzie pozwalające skonstruować poetykę zdolną do wyrażenia parapolitycznego charakteru nowoczesnych instytucji politycznych. Sam termin „parapolityka” pochodzi ze studiów nad bezpieczeństwem publicznym i odnosi się do splotu państwowości i działalności przestępczej, a szerzej do pozapolitycznych źródeł władzy politycznej oraz związków państwowych i pozapaństwowych aktorów. O ile zatem nowoczesna teoria polityczna przyjmuje za dobrą monetę publiczną działalność instytucji politycznych, obierając za przedmiot namysłu jej formalne i normatywne umocowanie, parapolityka zakłada istnienie nieodłącznej szczeliny między publicznym aspektem politycznych instytucji a tymi ich elementami, które realizowane są poza usankcjonowanym prawnie polem widzenia. Skierowanie uwagi na sferę niejawnych związków łączących instytucje polityczne, aparaty bezpieczeństwa i pozapolityczne organizacje nie ma jednak na celu demaskacji porządku politycznego (w takim sensie, w jakim demaskująca jest logika teorii spiskowej, oparta na dialektyce prawdy i pozoru), lecz wydobycie na jaw pewnej ontologicznej kondycji cechującej nowoczesny porządek polityczny, który pozostaje uwikłany w materialne warunki reprodukcji stosunku panowania, wykraczające poza zmonopolizowany aparat przemocy oraz ideologiczne aparaty państwa:

Nauki polityczne zakładają państwowość, zarówno w konstytucjonalnym, jak i normatywnym wymiarze, jako coś danego, badając zjawiska polityczne właśnie z perspektywy państwa. Parapolityka, przeciwnie, ustanawia radykalnie nominalistyczną krytykę konwencjonalnych studiów politycznych. Parapolityka posługuje się zmiennymi poziomami interakcji pomiędzy konwencjonalnymi państwami i bytami quasi-państwowymi jako podstawą dla sformułowania 
perspektywy analitycznej, która nie uprzywilejowuje ani państwa, ani jego alternatyw (Wilson 2009, 30).

Takie podejście do pytania o polityczność opiera się na napięciu pomiędzy roszczeniem do jedności, formułowanym przez tradycję, którą Wilson (dość ryzykownie) określa mianem postplatońskiego „politycznego monizmu” a różnymi wersjami politycznego pluralizmu. Chodzi więc o napięcie między nadrzędną figurą suwerena a rozproszonymi ośrodkami władzy, które lokalnie działają w ramach tej samej suwerennej logiki. Parapolityka dotyczy tego szczególnego momentu, w którym dochodzi do powiązania ze sobą monistycznie pojmowanej suwerenności z formami działania, które ze swej definicji podkopują wewnętrzną jedność władzy suwerennej - struktur mafijnych, organizacji paramilitarnych, korporacyjnych podmiotów gospodarczych. Zdaniem Wilsona teorie państwowej suwerenności formułowane w dobie nowożytnej okopują się na dwóch głównych stanowiskach: bądź to niepodzielności suwerenności, rozumianej jako gwarant państwowej jedności, bądź republikańskiej wizji suwerenności wpisanej w swoje materialne warunki możliwości (uznającej faktyczny pluralizm suwerennych aktorów konstytuujących ciało polityczne). Nie bez znaczenia jest oczywiście fakt, że sztandarowy teoretyk unitarystycznie pojmowanej władzy suwerennej, Jean Bodin, jest ideologiem kontynentalnej monarchii absolutnej, zaś teoretyk suwerenności umocowanej w prawie naturalnym, Hugo Grocjusz, konceptualizuje polityczne warunki stosunków międzynarodowych, w których działa flota holenderska ${ }^{8}$.

Tym, co prowadzi Wilsona od parapolitycznych studiów quasi-państwowych organizacji przestępczych i ich związków z instytucjami politycznymi liberalnej demokracji do kosmicznego horroru, jest próba wypracowania poetyki zdolnej uchwycić rozdźwięk pomiędzy humanistyczną i w istocie antropocentryczną wizją ciała politycznego a obojętną na normatywną treść instytucji politycznych, rzeczywistą parapolityczną cielesność, w której dochodzi do realizacji kryminalno-politycznej ekonomii, wspartej na poza-prawnych formach nacisku. Argument Wilsona

8 Bodin był nie tylko myślicielem politycznym, lecz również demonologiem, a jego pogląd na paktowanie z diabłem jako formę stowarzyszenia rozbijającą naturalną hierarchię bytów ustanowioną przez Boga dość dobrze pokazuje, że z punktu widzenia nowożytnej koncepcji suwerenności czarownica była postrzegana w kategoriach zagrożenia tyleż moralnego i religijnego, co społecznego (Bodin 1995, 56-62). Jak pokazuje Silvia Federici, prześladowania kobiet oskarżanych o czary stanowily strukturalnie istotny element kapitalistycznej akumulacji pierwotnej, w toku której zróżnicowane formy życia skupione wokół dóbr wspólnych wtłoczone zostały w społeczne struktury wczesnej nowoczesności (Federici 2004). 
sprowadza się więc do tego, że w tradycji politycznej uprzywilejowującej unitarystyczne koncepcje suwerenności, heterogeniczność aktorów politycznych mających pretensję do podejmowania suwerennych działań jest, estetycznie rzecz ujmując, przerażająca; uznając monistyczne roszczenia zawarte w pojęciu władzy suwerennej, musimy stwierdzić, że każda ekonomia polityczna zintegrowana z modelem władzy suwerennej musi posiadać aspekt kryminalny. Jak przekonuje Ola Tunander, stawką nie jest tutaj wcale delegitymizacja dominującego na Zachodzie modelu politycznego, lecz zakwestionowanie tego, że u jego podstaw faktycznie znajduje się unitarystyczna koncepcja suwerenności: „Problem z liberalizmem w naukach politycznych i teorii prawniczej nie polega na jego ambicji do obrony sfery publicznej, swobód politycznych i praw człowieka, lecz raczej na twierdzeniu, że te swobody i prawa definiują zachodni system polityczny" (Tunenberg 2009, 68).

Warto jednak zauważyć, że chodzi tutaj o coś więcej niż fakt, że suwerenna moc wprowadzenia stanu wyjątkowego jest przejawem głębszej parapolitycznej kondycji nowoczesnej aparatury politycznej. Jedność ciała politycznego zorganizowanego zgodnie logiką władzy suwerennej jest oparta na wewnętrznej spójności, traktującej organizm państwowy jak jednostkę, zaś parapolityczna perspektywa ma skupiać się na fakcie, że pomimo roszczenia do jedności nowoczesne ciało polityczne cechuje wielokształtność, która cały czas podlega kryminalizującym procesom translacji. Ostatecznie tym, co odpowiada za efekt grozy, nie jest więc idea przenikającej wszystko jedności - stanowiąca w istocie stały i oswojony motyw zachodniej myśli politycznej - lecz lęk przed tym, że możliwa jest inna polityka, opierająca się próbom przekładalności na unifikacyjny język władzy suwerennej.

Dokładnie takie doświadczenie odmowy przekładu na dyskurs nowoczesnych dyscyplin naukowych jest źródłem grozy, jakiej doświadcza narrator Zewu Cthulhu, przeglądając archiwum wycinków prasowych, dzienników i opracowań dotyczących tajemniczego kultu. Jest to groza zbudowana na konstatacji, że znajdujące się pod kontrolą i wypreparowane obiekty cechuje pewna wspólna kondycja, która jednocześnie nie daje się przełożyć na żaden z rozpoznawalnych dla nowoczesnego podmiotu dyskursów. Hipnotyczna zjawiskowość statuetki przedstawiającej chimeryczną istotę jest ściśle związana z faktem, że żaden z wybitnych specjalistów nie jest w stanie jej zaklasyfikować. Nie chodzi więc o samo potworne przedstawienie, lecz o fakt, że nie pozwala się ono uchwycić jako konkretny przedmiot, że łączy on ze sobą epoki i porządki estetyczne, które zgodnie z ustaleniami nowoczesnej nauki nie powinny mieć ze sobą nic wspólnego. Wspólnotowość, na przekór dyskursywnej 
separacji, grodzeniom i dyscyplinującej władzy, okazuje się katalizatorem lęku przed wspólnotą, która wybrzmiewa w jednej formule, dającej się wyłapać w rytmicznych śpiewach na nowoorleańskich bagnach, w tajemniczych inkantacjach powtarzanych przez Inuitów za kołem podbiegunowym, jak i w delirycznym mamrotaniu nowojorskich artystów: „Ph’nglui mglw' nafh Cthulhu R'lyeh wgah-nagl fhtagn”.

\section{Monizm i ontologia polityczna dóbr wspólnych}

W tym miejscu wypada się zatrzymać i zwrócić uwagę na kilka istotnych cech antymonistycznej tendencji istniejącej w ramach nowożytnej myśli europejskiej. Po pierwsze, w krytyce monizmu na przełomie siedemnastego i osiemnastego wieku istotną rolę odgrywa porządek wyobrażeniowy. Obrazy świata, w którym istnieje jedna tylko substancja są co najmniej równie istotne, jak filozoficzne argumenty, które mają one ilustrować. Po drugie, tytułowy lęk przed monizmem traktować należy przede wszystkim jako lęk przed niedającym się ujarzmić wspólnotowym naddatkiem, którego nie da się przetłumaczyć na język nowoczesnej racjonalistycznie zorientowanej metafizyki. Łatwo dostrzec to zwłaszcza w tendencji do interpretowania monizmu w kluczu panteistycznym, zgodnie z którym byt można pomyśleć jako zdolny do samostanowienia wyłącznie wtedy, gdy odnajdzie się w nim ślad bożej mocy, organizującej wszelkie istnienie wokół figury suwerena. Odruch pytania o to, co na płaszczyźnie immanencji mogłoby zastąpić suwerenny model władzy trudno interpretować inaczej niż jako próbę utrzymania monistycznej ontologii politycznej w ryzach układu wypracowanego wzdłuż teologiczno-platońskiego dziedzictwa europejskiej myśli politycznej. Po trzecie wreszcie, zarówno wyobrażeniowy aspekt krytyki monizmu, jak i nacisk położony na możliwość odtworzenia w jej ramach stosunków panowania umocowanych na figurze suwerenności znajduje swoje materialne osadzenie w kolonialnej ekspansji. Uwaga ta jest o tyle istotna, że zwracając uwagę na globalne uwikłanie nowożytnego antymonizmu, możemy dostrzec również jego związek z procesami, które tradycja marksistowska określa jako tak zwaną akumulację pierwotną. W istocie omawiane powyżej, Baylowskie żądanie wyraźnej zasady jednostkowienia i obrona podzielności substancji daje się z łatwością czytać w kontekście mechanizmów produkcji nowoczesnych form podmiotowości, które wyłaniają się w konsekwencji grodzeń i wywłaszczeń stanowiących konstytutywny moment kapitalistycznych stosunków społecznych (zob. Krzeski i Piekarska 2017). 
Nowożytny potwór

monizmu ujawnia się poprzez równoczesność

i równoważność każ-

dego partykularnego

określenia, które winno

zostać rozdzielone i

zindywidualizowane;

każda cecha powinna

zostać przypisana

poszczególnym obiek-

tom, które następnie

można ze sobą porów-

nywać i zestawiać zgodnie z prawidłami

rozumu.

Antymonistyczna reakcja zawiera więc podwójny gest krytyczny, którego rezultatem jest zepchnięcie monizmu na margines filozoficznego nurtu nowoczesności. Nowożytny potwór monizmu ujawnia się poprzez równoczesność i równoważność każdego partykularnego określenia, które winno zostać rozdzielone i zindywidualizowane; każda cecha powinna zostać przypisana poszczególnym obiektom, które następnie można ze sobą porównywać i zestawiać zgodnie z prawidłami rozumu. Ontologiczna równoważność musi zostać zapośredniczona, inaczej grozi ona nawarstwieniem wewnętrznych sprzeczności. Na bardzo podobne napięcie zwraca uwagę Joanna Bednarek omawiając nierozerwalny splot uniwersalistycznych roszczeń kapitału z odtwarzanymi nieprzerwanie procesami synchronizacji niewspółmiernych i partykularnych porządków historycznych istniejących w obrębie globalnego kapitalizmu. Jeden, uniwersalny czas nowoczesnej historii okazuje się przy bliższych oględzinach zlepkiem ledwie zsynchronizowanych ze sobą partykularnych, lokalnych czasowości, anachronicznych stosunków społecznych, politycznych aparatów i sposobów życia, które w jedną globalną całość łączy ze sobą imperialna maszyna translacyjna:

Logika kapitału kształtuje się w toku synchronizacji licznych i często niewspółmiernych czasowości, która narzuca im wspólną miarę; oba wymiary, logika i historia, są częścią jednego procesu, wytwarzającego efekt uniwersalności (który część marksistów bierze za ostateczną rzeczywistość), ale nigdy raz na zawsze, i zawsze kosztem pojawienia się nowych miejsc, w których może zaistnieć to, co niewspółmierne wobec kapitalistycznej synchronizacji (Bednarek 2015, 74).

Jeśli więc rzeczywiście wyobrażeniowe ujęcie monizmu w dobie nowożytnej pozwala zauważyć inną ontologię polityczną, to tylko o tyle, o ile wyraża się ona w pęknięciach i szczelinach procesów „synchronizacji” różnych porządków czasowych i ontycznych. Massimiliano Tomba podejmuje temat innych czasowości w książce Insurgent Universalities, przeciwstawiając mono-historii nowoczesności „pluriwersum” porządków historycznych, które cechuje nie tyle roszczenie do uniwersalności, co materialna równoważność, wzajemna przekładalność bez potrzeby zapośredniczenia w medium imperialnej maszyny translacyjnej. W tym kontekście kluczowa okazuje się nie tylko unifikująca tendencja nowoczesności, lecz także nieprzerwana produkcja zewnętrza, bez której procesy modernizacyjne, akumulacja pierwotna, globalna ekspansja kapitalizmu tracą normatywne umocowanie. W przenikliwym studium imperialnej optyki Ariella Aïsha Azoulay rozwija tę perspektywę, badając nowoczesne mechanizmy produkcji relacji zewnętrzności i łącząc je z nieprzerwaną 
produkcją obiektów i towarzyszących im klasyfikacji. Opisywana przez Azoulay operacja dzielenia świata na dwa ontycznie odrębne obszary, z których jeden znajduje się tutaj, drugi zaś tam, jest dzisiaj ściśle powiązana z nowożytnym rozumieniem substancji jako czegoś podzielnego i złożonego z części. Cechuje ją szczególny sposób postrzegania, u którego podstaw znajduje się idea transcendentnej władzy suwerennej, posiadająca moc przemienienia tego abstrakcyjnego podziału w rzeczywistą kondycję. Zdaniem Azoulay jego technologiczną realizacją jest aparat fotograficzny, który wyraża dużo starszą niż sam aparat dyspozycję poznawczą kolonizatora i odkrywcy. Ruch migawki w aparacie fotograficznym dokonuje geometrycznego podziału rzeczywistości, opartego na trzech liniach: „w czasie (pomiędzy tym co wcześniejsze i późniejsze), w przestrzeni (pomiędzy tym, kto/co znajduje się przed obiektywem i tym, kto/co stoi za nim) oraz w ciele politycznym (pomiędzy tymi, którzy posiadają i operują tego typu urządzeniami, akumulując ich wytwory a tymi, których rysy, zasoby i praca podlegają ekstrakcji)" (Azoulay 2019, 5). Azoulay zwraca również uwagę na fakt, że podziały te są prefigurowane w transcendentnej pozycji, jaką poznający podmiot zajmuje względem swojego przedmiotu. Zewnętrze jest najpierw zakładane, następnie zaś realizowane w akcie decyzji, której wykonawcą jest „mały suweren" poprzedzający każdy akt poznawczy:

Mały suweren potwierdza się w tym momencie jako poprzedzający i oddzielony od wydarzenia fotograficznego, od jego uczestniczek i od sytuacji, z której ma zostać wyekstrahowana fotografia. Rozkazuje on, jakie rzeczy mają być oddalone w głąb, usunięte, zapomniane, wyparte, zignorowane, przekroczone lub uznane za nieistotne dla działania migawki, jak i dla wykonania fotografii, której znaczenie ma zostać potem zaakceptowane (Azoulay 2019, 7).

Będący produktem takiej operacji obiekt stanowi zredukowaną do określonych parametrów technicznych pozostałość po danej formie wspólnego życia. Fotograficzne spojrzenie uchwytuje więc mechanizm do złudzenia przypominający aparaturę kartezjańskiej metafizyki, której fiasko w konfrontacji z monistyczną ontologią ilustrują w Bayle'owskiej refutacji odwołania do figury monstrualności i chimeryczności.

Odmowa przyjęcia imperialnej perspektywy polega przede wszystkim na odejściu od ujmowanej w kategoriach transcendencji idei suwerenności i powiązaniu wytworów imperialnej wiedzy (eksponatów, dokumentów archiwalnych i nowoczesnych kategorii politycznych) z konstytuującą je przemocą. Dla Azoulay stawką jest tutaj demontaż aparatury, za pomocą której nowoczesność ustanawia się jako pewna 
historyczna konieczność, poprzez raz po raz odtwarzane usunięcie z kadru swoich materialnych warunków możliwości: grodzeń, wywłaszczeń, wymuszonych migracji i rabunkowej eksploatacji. Wyjście poza narzuconą odgórnie siatkę nowoczesnych podziałów ma polegać na odzyskaniu historii wypartych i zniszczonych sposobów wspólnego życia, w których ulokowane są alternatywne wobec nowoczesnej suwerenności formy organizacji ciała politycznego. Kluczowym elementem w argumentacji Azoulay jest fakt, że możliwość odczynienia nowoczesnej historii opiera się nie na jej odrzuceniu, lecz rozpoznaniu jej przygodności i niemożliwości domknięcia procesów zawłaszczania dóbr wspólnych, konstytutywnych dla każdej formy życia społecznego:

Po wiekach imperializmu, to właśnie ta przemoc jest formą naszych dóbr wspólnych. Zamiast więc konceptualizować dobra wspólne wyłącznie w opozycji do sprywatyzowanej przestrzeni, jako dziedzinę zniszczoną przez kapitalizm i imperializm, do której odzyskania powinniśmy dążyć, uważam, że dobra wspólne nie są dającą się wybrać metodą współdzielenia życia, lecz konkretnym trybem, wedle którego życie jest współdzielone. Dobra wspólne wytwarzają się poprzez ludzkie bycie razem, nawet jeśli ludzie dzielą życie nie poprzez bycie ze sobą, lecz poprzez bycie przeciw sobie (Azoulay 2019, 148).

Takie ujęcie dóbr wspólnych jest zaskakująco zbieżne z obrazem monizmu, który znaleźliśmy u Bayle’a. Właściwym medium, w którym może wybrzmieć monistyczna wspólnota jest przemoc. Żaden z barwnych opisów cierpienia, jakie znajdujemy w Baylowskiej refutacji Spinozy nie jest wynikiem przyjęcia monistycznego obrazu świata. Węgrzy i Turcy masakrujący się nawzajem w bitewnym zmaganiu, samobójcy czy wijący się w męczarniach melancholicy nie są jakimiś fantastycznymi istotami, możliwymi do pomyślenia wyłącznie w świecie, w którym wszystko jest jednym ciałem. Przeciwnie, są one aż nadto dobrze znane i właśnie dlatego tak dobrze działają na wyobraźnię. Przyjęcie monistycznej perspektywy sprawia jednak, że przemoc i cierpienie tracą swój prywatny, zindywidualizowany charakter. Stają się wspólną sprawą, kłopotliwym dobrem wspólnym, które istotnie może wydawać się potworne dla nowoczesnej umysłowości, opętanej wizją suwerennej jednostki, dla której wyjściową formą bycia w świecie jest panowanie. 


\section{Wykaz literatury}

Azoulay, Ariella Aïsha. 2019. Potential History: Unlearning Imperialism. London - New York: Verso.

Bayle, Pierre. 1826. An Historical and Critical Dictionary. T. III. 4 t. Hunt and Clarke.

Bayle, Pierre. 2000. Various Thoughts on the Occasion of a Comet. Tłum. Robert C. Bartlett. New York: State University of New York Press. Bednarek, Joanna. 2014. „Emancypacyjna obietnica posthumanizmu.” Praktyka Teoretyczna 14(4): 171-180. https://doi.org/10.14746/ prt.2014.4.7.

Bednarek, Joanna. 2015. „Akumulacja pierwotna i czasowości kapitalizmu." Praktyka Teoretyczna 16(2): 56-77. https://doi.org/10.14746/ prt.2015.2.2.

Bednarek, Joanna. 2018. „ «Upojenie jako triumfalne wtargnięcie w nas rośliny»: obietnice i niebezpieczeństwa roślinnej seksualności." Teksty Drugie 2: 186-205. https://doi.org/10.18318/td.2018.2.12.

Bodin, Jean. 1995. On the Demon-Mania of Witches. Tłum. Randy A. Scott. Wstęp Jonathan L. Pearl. Toronto: Centre for Reformation and Renaissance Studies.

Carroll, Noël. 2003. The Philosophy of Horror: Or, Paradoxes of the Heart. New York - London: Routledge.

Charnley, Joy. 1990. „Near and Far East in the Works of Pierre Bayle.” The Seventeenth Century 5(2): 173-183. https://doi.org/10.1080/0 $268117 X .1990 .10555309$.

Federici, Silvia. 2004. Caliban and the Witch: Omen, the Body and Primitive Accumulation. New York: Autonomedia.

Gernet, Jacques. 1973. „La Politique de conversion de Matteo Ricci en Chine." Archives de sciences sociales des religions 36(18): 71-89.

Janik, Mateusz. 2020. „Imagining Immanent Causality: Depictions of Neo-Confucian and Spinozist Monism in the Works of Matteo Ricci and Pierre Bayle." Philosophy East and West, listopad. https://doi. org/10.1353/pew.0.0206.

Jensen, Lionel M. 1997. Manufacturing Confucianism: Chinese Traditions \& Universal Civilization. Durham: Duke University Press.

Kapoor, Ramesh. b.d. „Comet tales from India”.

Karl, Rebecca E. 2017. The Magic of Concepts: History and the Economic in Twentieth-Century China. Durham: Duke University Press.

Kowalczyk, Agnieszka. 2014. „Mapping Non-human Resistance in the Age of Biocapital." W The Rise of Critical Animal Studies - From the Margins to the Centre, red. Nick Taylor i Richard Twine, 183-200. 
London - New York: Routledge i Taylor \& Francis Group.

Krzeski, Jakub, i Anna Piekarska. 2017. „Autonomia oporu - Marks, Spinoza i akumulacja pierwotna." Praktyka Teoretyczna 25(3): 85-112. https://doi.org/10.14746/prt.2017.3.3.

Lamy. 1696. Le nouvel athéisme renversé, ou réfutation de Spinoza.

Lezra, Jacques. 2019. Untranslating Machines: A Genealogy for the Ends of Global Thought. [b.m.]: Rowman \& Littlefield International.

Longobardi, Niccolò. 1701. Traité sur quelques points de la religion des Chinois. Tłum. Louis de Cicé. Paris: Louis Guérin.

Lovecraft, Howard P. 2019. Zew Cthulhu. Tłum. Maciej Płaza. Czerwonka: Wydawnictwo Vesper.

Meek, Ronald L. 2011. Social Science and the Ignoble Savage. Cambridge: Cambridge University Press.

Moeller, Hans-Georg. 2018. „On Comparative and Post-Comparative Philosophy." W Appreciating the Chinese Difference: Engaging Roger T. Ames on Methods, Issues, and Roles, red. James Behuniak, 31-45. Albany: State University of New York Press.

Moll, Łukasz. 2017. „Sytuując to, co wspólne. De Angelis, Agamben i zewnętrze kapitalizmu." Praktyka Teoretyczna 25(3): 46-84. https:// doi.org/10.14746/prt.2017.3.2.

Mulsow, Martin. 2015. Enlightenment Underground: Radical Germany, 1680-1720. Charlottesville - London: University of Virginia Press.

Mungello, David Emil. 1989. Curious Land: Jesuit Accommodation and the Origins of Sinology. Honolulu: University of Hawaii Press.

Norden, Bryan W. Van. 2017. Taking Back Philosophy: A Multicultural Manifesto. Wstęp Jay L Garfield. New York: New York Columbia University Press.

Pagden, Anthony. 1986. The Fall of Natural Man: The American Indian and the Origins of Comparative Ethnology. Cambridge - New York: Cambridge University Press.

Park, Katharine, i Lorraine J. Daston. 1981. „Unnatural conceptions: The study of monsters in sixteenth- and seventeenth-century France and England.” Past \& Present 92(1): 20-54. https://doi.org/10.1093/ past/92.1.20.

Park, Peter K. J. 2013. Africa, Asia, and the History of Philosophy: Racism in the Formation of the Philosophical Canon, 1780-1830. Albany: State University of New York Press.

Peng-Yoke, Ho, i Ang Tian-Se. 1970. „Chinese Astronomical Records on Comets and "Guest Stars» in the Official Histories of Ming and Ch'ing and other Supplementary Sources." Oriens Extremus 17(1/2): 63-99. http://www.jstor.org/stable/43382376 
Perkins, Franklin. 2004. Leibniz and China: A Commerce of Light. Cambridge: Cambridge University Press.

Polo, Marco. 1975. Opisanie świata. Tłum. Anna Ludwika Czerny. Wstęp Marian Lewicki. Warszawa: Państwowy Instytut Wydawniczy. Pospiszyl, Michał. 2016. „Anomiczni Żonglerzy. Ciało polityczne i późnośredniowieczna maszyna antropologiczna." Praktyka Teoretyczna 19(1): 232-264. https://doi.org/10.14746/prt.2016.1.11.

Ricci, Matteo, i Nicolas Trigault. 1617. De Christiana expeditione apud sinas suscepta ab Societate Jesu. Ex P. Matthaei Riccii eiusdem Societatis commentariis Libri V: Ad S.D.N. Paulum V. In Quibus Sinensis Regni mores, leges, atque instituta, \& novae illius Ecclesiae difficillima primordia accurate \& summa fide describuntur. Gualterus.

Scott, James C. 2010. The Art of Not Being Governed: An Anarchist History of Upland Southeast Asia. Singapore: NUS Press.

Shaffer, Ellen. 1952. „Father Eusebio Francisco Kino And The Comet of 1680-1681.” The Historical Society of Southern California Quarterly 34(1): 57-70. https://doi.org/10.2307/41168323.

Silius, Vytis. 2020. „Diversifying Academic Philosophy: The Post-Comparative Turn and Transculturalism." Asian Studies 8(2): 257-280. https://doi.org/10.4312/as.2020.8.2.257-280.

Szadkowski, Krystian, i Jakub Krzeski. 2019. „Political Ontologies of the Future University: Individual, Public, Common.” Philosophy and Theory in Higher Education 3(1): 29-49.

Tatián, Diego. 2014. „The Potentiality of the Archaic: Spinoza and the Chinese." Journal of the British Society for Phenomenology 45(1): 72-83. https://doi.org/10.1080/00071773.2014.915645.

Thacker, Eugene. 2011. In the Dust of This Planet: Horror of Philosophy Vol. 1. Lanham: John Hunt Publishing.

Tunenberg, Ola. 2009. „Democratic State vs. Deep State.” W Government of the Shadows: Parapolitics and Criminal Sovereignty, red. Eric Wilson. New York: Pluto Press.

Wilson, Eric. 2009. Government of the Shadows: Parapolitics and Criminal Sovereignty. New York: Pluto Press.

Wilson, Eric. 2016. The Republic of Cthulhu: Lovecraft, the Weird Tale, and Conspiracy Theory. Punctum Books. E-book. 
MATEUSZ JANIK - doktoryzował się w Instytucie Filozofii i Socjologii PAN. Członek redakcji czasopisma naukowego Praktyka Teoretyczna. Zajmuje się związkami polityki i metafizyki, etyką i krytyczną analizą szeroko rozumianej tradycji humanistycznej. Interesuje się również granicznymi momentami filozoficznego dyskursu nowoczesności oraz sposobami myślenia i bycia, które nie mieszczą się w jego ramach. Autor tekstów dotyczących filozofii nowożytnej oraz współczesnych nurtów myśli społecznej.

\section{Dane adresowe:}

Instytut Studiów Politycznych PAN

Polna 18/20

Warszawa 00-625

email: janikm@isppan.waw.pl

\section{Cytowanie:}

Janik, Mateusz. 2020. „Lęk przed monizmem: Potworność, parapolityka i nowożytne źródła filozofii porównawczej.” Praktyka Teoretyczna 3(37): 45-78.

DOI: $10.14746 / \operatorname{prt} 2020.3 .3$

Author: Mateusz Janik

Title: The fear of monism: Monstrosity, parapolitics, and early modern sources of the comparative philosophy

Abstract: This text analysis the ways in which monism was depicted as a doctrine situated on the crossroads of European and Asian philosophical traditions. The depiction of monism as monstrous, characteristic of the mainstream of early modern European thought, is set against the wider context of parapolitical critique of the concept of sovereignty and the cosmic horror concept. This juxtaposition is founded on the simultaneous lecture of the entry "Spinoza" in Pierre Bayle's An Historical and Critical Dictionary and Howard P. Lovecraft's story The Call of Cthulhu. In the article's conclusion the author argues that monism should be treated as one of the currents of collectively orientated political ontology. This ontology may provide a basis for a new model of comparative studies, centred around the concept of commons, and critical towards modern cognitive-political framework, sustaining and naturalising the primitive accumulation processes.

Keywords: early modernity, commons, parapolitics, monism, ontology 